\title{
Phosphate Desorption Characteristics of Some Representative Soils of Bangladesh: Effect of Exchangeable Anions, Water Molecules and Solution to Soil Ratios
}

\author{
Mohammad Z. Afsar ${ }^{1 *}$, Sirajul Hoque ${ }^{2}$, Khan Towhid Osman ${ }^{1}$ \\ ${ }^{1}$ Department of Soil Science, Faculty of Biological Sciences, University of Chittagong, Chittagong, Bangladesh; ${ }^{2}$ Department of Soil, \\ Water and Environment, Faculty of Biological Sciences, University of Dhaka, Dhaka, Bangladesh. \\ Email: *zafarbd_1982@yahoo.com
}

Received June 27 ${ }^{\text {th }}, 2012$; revised August $28^{\text {th }}, 2012$; accepted September $10^{\text {th }}, 2012$

\begin{abstract}
Establishment of phosphate $(\mathrm{P})$ retention and release capacity of soils is essential for effective nutrient management and environmental protection. In this experiment, we studied the influence of soil properties on $\mathrm{P}$ desorption and the relationship between phosphate sorption and desorption. Among the soil series, the Ghior soil had the highest percent clay $(59.32 \%)$ and free iron oxide $\left(15,241 \mathrm{mg} \cdot \mathrm{kg}^{-1}\right)$ content. Along the catena of the calcareous soils, percent clay contents increased. For sorption study, the soils were equilibrated with $0.01 \mathrm{M} \mathrm{CaCl}_{2}$ solution containing $0,1,2,4,8,16,25,50$, 100 and $150 \mathrm{mg} \cdot \mathrm{P} \cdot \mathrm{L}^{-1}$ solution. For desorption, three extractants namely, $\mathrm{SO}_{4}^{2-}(0.005 \mathrm{M})$ as $\mathrm{Na}_{2} \mathrm{SO}_{4}, \mathrm{HCO}_{3}^{-}(0.01$ $\mathrm{M})$ as $\mathrm{NaHCO}_{3}$ and distilled water were used at extractant to soil ratios of 30:1, 60:1 and 100:1 (v/w). Among the sorption equations, the Langmuir equation showed better fit to the sorption data at higher P concentrations. The amount of phosphate desorbed by all the three extractants increased significantly with the increasing extractant to soil ratios. Phosphate desorption by $\mathrm{SO}_{4}^{2-}$ and water molecules was highly correlated with $\mathrm{pH}$, percent clay and free iron oxide content of the soil. Significant positive correlation $(r>0.64, \mathrm{P}<0.05)$ was observed between the amount of phosphate desorption and phosphate sorption maximum $\left(\mathrm{b}_{\mathrm{L}}\right)$. Phosphate desorption by $\mathrm{SO}_{4}^{2-}$ and water molecules was also positively correlated with Freundlich constant, N $(r>0.67, \mathrm{P}<0.05)$ and $\mathrm{EPC}_{0}(\mathrm{r}>0.72, \mathrm{P}<0.05)$. On the other hand, a significant negative correlation $(\mathrm{r}>-0.77, \mathrm{P}<0.05)$ was observed between phosphate desorption and phosphate binding strength $\left(\mathrm{K}_{\mathrm{L}}\right)$. The results suggest that freshly sorbed phosphate ions (inner-sphere complex forming species) can be readily desobed by outer-sphere complex forming species like sulphate and bicarbonate ions. Water molecules also desorbed significant amount of freshly sorbed phosphate from the soil colloids.
\end{abstract}

Keywords: Phosphate Sorption; Extractant to Soil Ratio; Surface Complexation of Anions; Labile Forms of P; Phosphate Desorption

\section{Introduction}

Phosphorus $(\mathrm{P})$ is the second most important nutrient, next to nitrogen $(\mathrm{N})$ that has often been found limiting biological productivity in terrestrial environments and as well as in surface water environments. Management of phosphate fertilization is essential for maintaining the concentration of biologically available soil-P at a value adequate for plant growth, while minimizing the movement of dissolved-P and particulate-P to surface water and shallow groundwater. Soils also have a defined capacity to adsorb phosphorus and there will be a great possibility to release excess $\mathrm{P}$ into the surface or ground water when a critical $P$ sorption saturation level is at-

"Corresponding author. tained [1]. It is, therefore, crucial to predict the partitioning of applied P fertilizer between soil solid phase and soil solution which can be achieved by studying the $\mathrm{P}$ sorption-desorption behavior of soil. Phosphate sorption plays an important role in environmental aspects of $\mathrm{P}$ management. Batch incubation studies are generally used to estimate P sorption capacity of soil. The capacity of soil to retain added $\mathrm{P}$ is often described by simple adsorption equations, which relate $\mathrm{P}$ concentration in solution to the amount of $\mathrm{P}$ retained by the soil [2]. The most popular mathematical models used to describe $\mathrm{P}$ sorption are the Langmuir and Freundlich equations [3]. Temkin equation is also used to describe phosphate sorption in soil [4].

Phosphate $\left(\mathrm{H}_{2} \mathrm{PO}_{4}^{-}\right)$, bicarbonate $\left(\mathrm{HCO}_{3}^{-}\right)$and sul- 
phate $\left(\mathrm{SO}_{4}^{2-}\right)$ are three important adsorptive, nonpolymeric anions that are present in soil solution. The mechanisms by which these anions are adsorbed to the colloid particles are surface complexation and diffuse-ion swarm association. Outer-sphere complexation of anions involves coordination to a protonated hydroxyl or amino group or to a surface metal cation. On the other hand, inner-sphere surface complexation of anions involves coordination to created or native Lewis acid sites. The anions like bicarbonate $\left(\mathrm{HCO}_{3}^{-}\right)$and sulphate $\left(\mathrm{SO}_{4}^{2-}\right)$ are considered to be adsorbed mainly as outer-sphere complex species. These ions are readily exchangeable and often exhibit a negative surface excess in permanent-charge soils. In contrast, phosphate $\left(\mathrm{H}_{2} \mathrm{PO}_{4}^{-}\right)$is considered to be adsorbed principally as inner-sphere complex species [5]. When the orthophosphate ion is bonded through one Al-O-P bond (a single coordinate linkage), the ion is considered labile and the adsorption is said to be reversible. This orthophosphate ion can be readily desorbed from the mineral surface to soil solution [6,7].

Phosphate desorption in soil can be enhanced by increasing the negative charge on the surface of soil particles either by raising the solution $\mathrm{pH}$, or by introducing a competitive anion. These competitive ions will increase the negative charge of the soil in the presence of P. Unequal ion distribution in the charged colloid surfaces, surrounded by diffuse double layer (DDL), causes anion repulsion or negative adsorption. The negative adsorption is governed by 1) anion charge and concentration, 2) species of exchangeable cation, 3) $\mathrm{pH}, 4$ ) presence of other anions and 5) nature and charge of the colloid surface [8]. In a freshly phosphate sorbed soil, addition of bicarbonate and sulphate ions may have some influence on phosphate desorption.

The rate of phosphate desorption has also been found to be largely a function of the solution to soil ratio. During a $\mathrm{P}$ desorption event, if the solution to soil ratio increases, for example because of an increase in soil water content or in the amount of runoff, $\mathrm{P}$ will desorb from the soil to maintain an equilibrium between the soil sorbed $\mathrm{P}$ and the solution P. Phosphate desorption in a poorly buffered soil is more influenced by changes in solution to soil ratios [9-11]. However, varying the solution to soil ratio has produced conflicting results in regard to the amount of P extracted. Some scientists [12] reported that adsorption was least with a small solution to soil ratio. Whereas, other scientists [13] found that adsorption was smallest with a large solution to soil ratio.

Soil properties affecting the $\mathrm{P}$ adsorption capacity are soil texture [14], organic matter [15], oxides of iron and aluminium [16], soil $\mathrm{pH}$ [17] and $\mathrm{CaCO}_{3}$ content [18]. Even in calcareous soils, hydrous oxides are important for adsorption of $\mathrm{P}$ [19].
The objectives of this experiment were, therefore, to 1) estimate phosphate desorption pattern of soils as controlled by different soil extractants at different extractant to soil ratios, 2) study the effects of different soil properties on phosphate desorption and 3) identify the relationship between different phosphate sorption parameters and phosphate desorption.

\section{Materials and Methods}

\subsection{Soil Series}

In the present study, five non-calcareous and three calcareous soil series were studied. The Baliadangi series (Eutric Cambisol) of Old Himalayan Piedmont Plain, the Gongachara series (Eutric Fluvisol) of Tista Meander Floodplain, the Lockdeo (Eutric Fluvisol), the Silmandi (Eutric Fluvisol) and the Ghatail series (Eutric Fluvisol) of Old Brahmaputra Floodplain are non-calcareous soils. On the other hand, the Gopalpur (Calcaric Fluvisol), the Ishurdi (Calcaric Fluvisol), and the Ghior (Calcaric Fluvisol) series of Low Ganges River Floodplain are calcareous in their origin. The soils are grouped according to the World reference base for soil resources 2006 [20]. The three calcareous soil series comprised a catena, with the Gopalpur and the Ghior soil series being located at the highest and the lowest elevation, respectively.

\subsection{Soil Sample Collection}

Soil samples at a depth of $0-15 \mathrm{~cm}$ were collected from 20 spots from a square area of $\sim 1 \mathrm{~km}^{2}$ under a soil series. Approximately equal amounts (on weight basis) of these samples were mixed together to form a composite sample. The soils were then air dried at room temperature $\left(25^{\circ} \mathrm{C}\right.$ $\pm 2^{\circ} \mathrm{C}$ ) for 7 days, ground and passed through a $2 \mathrm{~mm}$ sieve.

\subsection{Analysis}

The soil samples were analyzed for particle size analysis, $\mathrm{pH}$, Olsen-P, Total P, organic matter, free carbonate and fractions of iron. Particle size analysis was done by Bouyoucos hydrometer method [21]. Soil organic matter content was calculated by multiplying the percent organic carbon by the conversion factor of 1.724 . Soil organic carbon was determined by Walkley-Black's wet oxidation with $1 \mathrm{~N} \mathrm{~K}_{2} \mathrm{Cr}_{2} \mathrm{O}_{7}$ method [22]. Soil $\mathrm{pH}$ was determined at soil to water ratio of 1:2.5. Total $\mathrm{P}$ content of the soil was determined after digestion with $\mathrm{HNO}_{3}$ $\mathrm{HClO}_{4}$ mixture [23]. Olsen-P was extracted by $0.5 \mathrm{M}$ $\mathrm{NaHCO}_{3}$ at $\mathrm{pH} 8.5$ [24]. Subsequent P determination was carried out by following ascorbic acid blue color method [25]. Free carbonate contents of the calcareous soil samples were determined by following rapid titration method. 
$1 \mathrm{M} \mathrm{HCl}$ solution was used at soil to extractant ratio of $1: 20$ [26]. For the determination of free iron oxide content, $0.5 \mathrm{~g}$ soil was transferred to a centrifuge tube. Then $0.5 \mathrm{~g} \mathrm{Na}_{2} \mathrm{~S}_{2} \mathrm{O}_{4}$ and $6.0 \mathrm{~g}$ Na-citrate and $30 \mathrm{ml}$ deionized water was added. The tubes were shaken for 16 hours [27]. Ammonium oxalate ( $\mathrm{pH}$ 3.0) was used to determine "Active" or "Amorphous" iron oxides. The tubes were shaken for 2 hours. In case of calcareous soils, $1 \mathrm{M} \mathrm{NH}_{4}$ acetate $(\mathrm{pH} 5.5)$ solution was added and shaken for an hour [28]. Sodium pyrophosphate extractant ( $\mathrm{pH} \mathrm{10)}$ was used for the estimation of organically bound Fe [29]. Iron was determined colorimetrically by reduction of $\mathrm{Fe}$ with hydroxylamine hydrochloride and reaction with 1,10phenanthroline to form the tris (1,10-phenanthroline) Fe(II) complex, which had a red color [30]. All determinations were done in triplicate.

\subsection{Phosphate Sorption Procedures}

One gram soil sample was equilibrated in a centrifuge tube with $20 \mathrm{~mL} 0.01 \mathrm{M} \mathrm{CaCl}_{2}$ solution containing 0,1 , $2,4,8,16,25,50,100$ and $150 \mathrm{mg} \cdot \mathrm{P} \cdot \mathrm{L}^{-1}$ (equivalent to 0 , $20,40,80,160,320,500,1000,2000$, and 3000 $\mathrm{mg} \cdot \mathrm{P} \cdot \mathrm{kg}^{-1}$ soil) as $\mathrm{KH}_{2} \mathrm{PO}_{4}$. Then the soil samples were incubated at room temperature $\left(25^{\circ} \mathrm{C} \pm 2^{\circ} \mathrm{C}\right)$ for 3 days [31]. The samples were then centrifuged at $4500 \mathrm{rpm}$ for 15 minutes and filtered through Whatmanfilter paper No. 42. The $\mathrm{P}$ in solution was determined colorimetrically by the molybdate blue colour method [25]. The data were then plotted according to the Langmuir, Freundlich and Temkin equations.

Linear form of the Langmuir equation is

$$
\mathrm{C} / \mathrm{X}=1 / \mathrm{K}_{\mathrm{L}} \mathrm{b}_{\mathrm{L}}+\mathrm{C} / \mathrm{b}_{\mathrm{L}}[32]
$$

$\mathrm{X}=$ amount of $\mathrm{P}$ sorbed $\left(\mathrm{mg} \cdot \mathrm{kg}^{-1}\right), \mathrm{C}=$ equilibrium $\mathrm{P}$ concentration $\left(\mathrm{mg} \cdot \mathrm{L}^{-1}\right)$ in solution, $\mathrm{b}_{\mathrm{L}}=$ adsorption maximum $\left(\mathrm{mg} \cdot \mathrm{P} \cdot \mathrm{kg}^{-1}\right), \quad \mathrm{K}_{\mathrm{L}}=$ bonding energy constant $\left(\mathrm{L} \cdot \mathrm{mg}^{-1} \cdot \mathrm{P}\right)$. A plot of $\mathrm{C} / \mathrm{X}$ (y-axis variable) against $\mathrm{C}$ ( $\mathrm{x}$-axis variable) will yield a straight line with a slope of $1 / b_{L}$ and a y-intercept of $1 / K_{L} b_{L}$.

Freundlich equation is

$$
\mathrm{X}=\mathrm{K}_{\mathrm{f}} \mathrm{C}^{\mathrm{N}}[33]
$$

Logarithmic form of the Freundlich Equation is

$$
\log \mathrm{X}=\log \mathrm{K}_{\mathrm{f}}+\mathrm{N} \log \mathrm{C}
$$

$\mathrm{X}=$ amount of $\mathrm{P}$ sorbed $\left(\mathrm{mg} \cdot \mathrm{kg}^{-1}\right), \mathrm{C}=$ equilibrium $\mathrm{P}$ concentration $\left(\mathrm{mg} \cdot \mathrm{L}^{-1}\right)$ in solution, $\mathrm{K}_{\mathrm{f}}=$ proportionality constant $\left(\mathrm{mg} \cdot \mathrm{kg}^{-1}\right), \mathrm{N}=$ empirical constant related to bonding energy of soil for phosphate. A plot of $\log X$ (y-axis variable) against $\log \mathrm{C}(\mathrm{x}$-axis variable) will yield a straight line with slope $\mathrm{N}$ and a y-intercept of $\log \mathrm{K}_{\mathrm{f}}$.

Temkin equation is

$$
\mathrm{X}=\mathrm{a}+\mathrm{b} \log \mathrm{C}[4]
$$

$\mathrm{X}=$ amount of $\mathrm{P}$ sorbed $\left(\mathrm{mg} \cdot \mathrm{kg}^{-1}\right), \mathrm{C}=$ equilibrium $\mathrm{P}$ concentration $\left(\mathrm{mg} \cdot \mathrm{L}^{-1}\right)$ in solution, $\mathrm{a}$ and $\mathrm{b}$ are constants. A plot of $\mathrm{X}$ (y-axis variable) against $\log \mathrm{C}(\mathrm{x}$-axis variable) will yield a straight line with slope $b$ and $y$-intercept a. The fitted Temkin equation is used to determine the equilibrium $\mathrm{P}$ concentration $\left(\mathrm{EPC}_{0}\right)$ for each of the soils, by determining the value of $\mathrm{X}$ when $\mathrm{C}$ equaled zero.

\subsection{Phosphorus Desorption Procedures}

Initially soil samples were sorbed with $100 \mathrm{mg} \cdot \mathrm{P} \cdot \mathrm{L}^{-1}$ as $\mathrm{KH}_{2} \mathrm{PO}_{4}$ at room temperature $\left(25^{\circ} \mathrm{C} \pm 2^{\circ} \mathrm{C}\right)$ for 3 days prior to the desorption study. The soil suspension was filtered and the residue was washed with $10 \mathrm{~mL}$ distilled water for two times to remove excess phosphate ions, which were not sorbed by the soil samples. Then the soil samples were air-dried $\left(25^{\circ} \mathrm{C} \pm 2^{\circ} \mathrm{C}\right)$ for a week and were preserved for desorption studies.

Phosphate sorbed soil samples and extractants were taken in centrifuge tubes at extractant to soil ratios of 30:1, 60:1 and 100:1 (v/w).Three extractants namely, $0.005 \mathrm{M} \mathrm{SO}_{4}^{2-}$ as $\mathrm{Na}_{2} \mathrm{SO}_{4}, 0.01 \mathrm{M} \mathrm{HCO}_{3}^{-}$as $\mathrm{NaHCO}_{3}$ and distilled water $\left(\mathrm{H}_{2} \mathrm{O}\right)$ were used. All determinations were done in triplicate. The contents were shaken on a horizontal shaker for 180 minutes. The samples were then centrifuged at $4500 \mathrm{rpm}$ for 15 minutes and filtered through Whatmanfilter paper No. 42. The P in solution was determined colorimetrically by the molybdate blue colour method [25].

\subsection{Statistical Analysis}

The incubation experiment was arranged in the laboratory according to a factorial combination. The factors were soil series, extractants and extractant to soil ratios. Analysis of variance (ANOVA) and correlation analyses were performed by using SPSS-16 statistical software.

\section{Results}

\subsection{Physical and Chemical Properties of the Soils}

The soils are representative of the major soil types in Bangladesh and exhibit a wide range of properties (Table 1). The $\mathrm{pH}$ of the soils ranged from 5.33 to 7.65 with an average value of 6.4. The percent clay content of the soils varied from 20.30 to 59.32 , with the Lokdeo and the Ghior soil series having the smallest and the largest values, respectively. Organic matter content of the soils ranged between 1.55 and $3.77 \%$. The Olsen-P content varied from 21.25 to $63.70 \mathrm{mg} \cdot \mathrm{kg}^{-1}$ soil. Among the three fractions of iron, free iron oxide ranged from 3524 15,241 , amorphous iron oxide from 1131 - 4260 and organically bound iron from $707-1965 \mathrm{mg} \cdot \mathrm{kg}^{-1}$ soil. 
Exchangeable Anions, Water Molecules and Solution to Soil Ratios

Table 1. Selected physical and chemical properties of the soil samples.

\begin{tabular}{cccccccccc}
\hline Soil series & $\begin{array}{c}\% \\
\text { Clay }\end{array}$ & $\mathrm{pH}$ & $\mathrm{OM}^{1}(\%)$ & $\begin{array}{c}\text { Total P } \\
(\%)\end{array}$ & $\begin{array}{c}\text { Olsen P } \\
\left(\mathrm{mg} \cdot \mathrm{kg}^{-1}\right)\end{array}$ & $\begin{array}{c}\text { Free } \\
\text { Carbonate }(\%)\end{array}$ & $\begin{array}{c}\text { Free Iron Oxide } \\
\left(\mathrm{mg} \cdot \mathrm{kg}^{-1}\right)\end{array}$ & $\begin{array}{c}\text { Amorphous Iron } \\
\left(\mathrm{mg}^{-1} \mathrm{~kg}^{-1}\right)\end{array}$ & $\begin{array}{c}\text { Organically } \\
\text { Bound Iron } \\
\left(\mathrm{mg} \cdot \mathrm{kg}^{-1}\right)\end{array}$ \\
\hline Baliadangi & $27.95^{\mathrm{f}}$ & $5.53^{\mathrm{f}}$ & $3.77^{\mathrm{a}}$ & $0.070^{\mathrm{d}}$ & $50.92^{\mathrm{b}}$ & - & $6254^{\mathrm{e}}$ & $1131^{\mathrm{h}}$ & $1275^{\mathrm{c}}$ \\
Gangachara & $35.30^{\mathrm{d}}$ & $5.33^{\mathrm{g}}$ & $2.49^{\mathrm{c}}$ & $0.071^{\mathrm{d}}$ & $63.70^{\mathrm{a}}$ & - & $5648^{\mathrm{f}}$ & $1749^{\mathrm{f}}$ & $1689^{\mathrm{b}}$ \\
Lokdeo & $20.30^{\mathrm{g}}$ & $5.68^{\mathrm{e}}$ & $1.55^{\mathrm{g}}$ & $0.068^{\mathrm{d}}$ & $27.40^{\mathrm{ef}}$ & - & $3524^{\mathrm{h}}$ & $1861^{\mathrm{e}}$ & $1241^{\mathrm{d}}$ \\
Silmandi & $29.50^{\mathrm{ef}}$ & $5.68^{\mathrm{e}}$ & $1.89^{\mathrm{e}}$ & $0.074^{\mathrm{d}}$ & $45.66^{\mathrm{c}}$ & - & $4528^{\mathrm{g}}$ & $3267^{\mathrm{c}}$ & $965^{\mathrm{f}}$ \\
Ghatail & $41.20^{\mathrm{c}}$ & $6.83^{\mathrm{d}}$ & $2.75^{\mathrm{b}}$ & $0.084^{\mathrm{c}}$ & $21.25^{\mathrm{g}}$ & - & $8654^{\mathrm{c}}$ & $4260^{\mathrm{a}}$ & $1206^{\mathrm{e}}$ \\
Gopalpur & $31.50^{\mathrm{e}}$ & $7.29^{\mathrm{b}}$ & $2.73^{\mathrm{b}}$ & $0.141^{\mathrm{a}}$ & $29.91^{\mathrm{de}}$ & 3.85 & $6354^{\mathrm{d}}$ & $1557^{\mathrm{g}}$ & $779^{\mathrm{g}}$ \\
Ishurdi & $45.20^{\mathrm{b}}$ & $7.07^{\mathrm{c}}$ & $2.33^{\mathrm{d}}$ & $0.134^{\mathrm{a}}$ & $23.74^{\mathrm{f}}$ & 5.78 & $10524^{\mathrm{b}}$ & $2647^{\mathrm{d}}$ & $707^{\mathrm{h}}$ \\
Ghior & $59.32^{\mathrm{a}}$ & $7.65^{\mathrm{a}}$ & $1.78^{\mathrm{f}}$ & $0.124^{\mathrm{b}}$ & $33.33^{\mathrm{d}}$ & 4.02 & $15241^{\mathrm{a}}$ & $3350^{\mathrm{b}}$ & $1965^{\mathrm{a}}$ \\
\hline
\end{tabular}

${ }^{1} \mathrm{OM}=$ organic matter; The values followed by the same letter(s) in a column(s) are not statistically different at $\mathrm{P}<0.05$.

\subsection{Phosphate Sorption Behavior}

The $\mathrm{P}$ sorption in soil increased with the increasing levels of $\mathrm{P}$ added to the soil. At equilibrium-solution concentration of $\mathrm{P}$ below $1.0 \mathrm{mg} \cdot \mathrm{L}^{-1}$, the relationship was approximately linear for most soils. While at higher equilibrium $\mathrm{P}$ concentrations, deviation from the linearity was observed. The linear part of the relationship was probably due to the large intermolecular distance between $\mathrm{P}$ molecules, which resulted in negligible mutual repulsion $[34,35]$. Among the non-calcareous soils, the Baliadangi soil was more retentive than the other four soils. The Ghior soil series, which was present at the bottom of the catena of Lower Ganges Floodplain, was more retentive than the other two calcareous soils and it also sorbed more than any of the non-calcareous soils. The Gopalpur series, located at the highest elevation in the catena sorbed the least amount of phosphate, while the Ishurdi soil was intermediate in its sorption properties.

The phosphate sorption data were plotted and the different sorption parameters were calculated according to the Freundlich, Langmuir and Temkin equations (Table 2). The Langmuir sorption maxima $\left(b_{L}\right)$ of the soil ranged from 416 to $1000 \mathrm{mg} \cdot \mathrm{kg}^{-1}$ and the binding energy constant varied from 0.08 to 0.25 . The $\mathrm{N}$ values of Freundlich equation were between 0.39 and $0.59 \mathrm{~L} \cdot \mathrm{kg}^{-1}$. The $\mathrm{EPC}_{0}$ values varied from 0.05 to 0.26 . The Ghior soil series, which had the highest clay and free iron oxide contents, also had the largest values of $\mathrm{N}, \mathrm{b}_{\mathrm{L}}$ and $\mathrm{EPC}_{0}$.

\subsection{Phosphate Desorption Behavior}

The amount of phosphate desorbed by different extractants increased with the increasing extractant to soil ratios (Table 3). Among the three extractants, $0.01 \mathrm{M}$ $\mathrm{HCO}_{3}^{-}$extracted the greatest percentage of the sorbed phosphate from the soils. In the non-calcareous soils,
$0.01 \mathrm{M} \mathrm{HCO}_{3}^{-}$removed $27.44 \%$ and $55.14 \%$ of the sorbed $\mathrm{P}$ at the smallest and the largest extractant to soil ratios. In contrast, $0.005 \mathrm{M} \mathrm{SO}_{4}^{2-}$ and distilled water desorbed only $15.24 \%$ and $18.36 \%$ of the sorbed $\mathrm{P}$ at the smallest extractant to soil ratios, respectively. The respective values at the largest extractant to soil ratio were $29.05 \%$ and $28.11 \%$. Similar desorption patterns were also observed in calcareous soils. Among the calcareous soils, the maximum phosphate desorption was observed in the Ishurdi soil series, where the P desorption was increased from $29.03 \%$ to $51.33 \%, 32.48 \%$ to $56.64 \%$ and $31.78 \%$ to $51.23 \%$ with the increasing extractant to soil

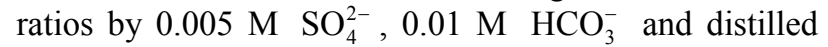
water, respectively.

To determine whether the variations in the phosphate desorption due to different factors were significant or not, analysis of variance (ANOVA) was done taking into account the soil series, types of extractants and the extractant to soil ratios as the sources of variation (Table 4). Among the three extractants, $0.01 \mathrm{M} \mathrm{HCO}_{3}^{-}$desorbed significantly higher amount of phosphate $(\mathrm{P}<0.001)$ than the other two extractants. Significant variations $(\mathrm{P}<$ 0.001) were also observed among the amounts of $\mathrm{P}$ desorbed at the three extractant to soil ratios. The studied soil series were also significantly $(\mathrm{P}<0.001)$ varied in their phosphate desorption capacity.

We evaluated the relationship between the phosphate desorption data and selected soil properties (Table 5) to get information about main soil properties responsible for phosphate desorption. The amounts of phosphate desorbed by both $\mathrm{SO}_{4}^{2-}$ and distilled water were significantly correlated with $\mathrm{pH}, \%$ clay and free iron oxide content of the soils $(\mathrm{r}>0.66, \mathrm{P}<0.05)$. However, for $\mathrm{HCO}_{3}^{-}$, no relationship was observed. In a previous study [34], the phosphate sorption capacity of soils was observed to be highly correlated with \% clay and free 
Table 2. Fitted Freundlich, Langmuir and Temkin equations for different soil series.

\begin{tabular}{|c|c|c|c|c|c|c|c|c|}
\hline \multirow{2}{*}{ Soil series } & \multicolumn{3}{|c|}{ Freundlich Equation } & \multicolumn{3}{|c|}{ Langmuir Equation } & \multicolumn{2}{|l|}{ Temkin Equation } \\
\hline & $\log X=\log K_{f}+N \log C$ & $\mathrm{~N}\left(\mathrm{~L} \cdot \mathrm{Kg}^{-1}\right)$ & $\mathrm{K}_{\mathrm{f}}\left(\mathrm{L} \cdot \mathrm{Kg}^{-1}\right)$ & $\mathrm{C} / \mathrm{X}=1 / \mathrm{K}_{\mathrm{L}} \mathrm{b}_{\mathrm{L}}+\mathrm{C} / \mathrm{b}_{\mathrm{L}}$ & $\mathrm{b}_{\mathrm{L}}\left(\mathrm{mg} \cdot \mathrm{P} \cdot \mathrm{kg}^{-1}\right)$ & $\mathrm{K}_{\mathrm{L}}$ & $X=a+b \log C$ & $\mathrm{EPC}_{0}$ \\
\hline Baliadangi & $\begin{array}{c}\mathrm{Y}=0.4387 \mathrm{x}+2.0396 \\
\mathrm{R}^{2}=0.99\end{array}$ & 0.44 & 108.29 & $\begin{array}{c}\mathrm{y}=0.0011 \mathrm{x}+0.0118 \\
\mathrm{R}^{2}=0.95\end{array}$ & 909.09 & 0.09 & $\begin{array}{c}\mathrm{y}=210.61 \mathrm{x}+218.44 \\
\mathrm{R}^{2}=0.80\end{array}$ & 0.09 \\
\hline Gangachara & $\begin{array}{c}y=0.386 x+2.08 \\
R^{2}=0.98\end{array}$ & 0.39 & 120.23 & $\begin{array}{c}\mathrm{y}=0.0014 \mathrm{x}+0.0091 \\
\mathrm{R}^{2}=0.98\end{array}$ & 714.29 & 0.15 & $\begin{array}{c}y=167.5 x+223.83 \\
R^{2}=0.85\end{array}$ & 0.05 \\
\hline Lokdeo & $\begin{array}{c}y=0.4066 x+1.8615 \\
R^{2}=0.97\end{array}$ & 0.41 & 72.69 & $\begin{array}{c}\mathrm{y}=0.0024 \mathrm{x}+0.0125 \\
\mathrm{R}^{2}=1.0\end{array}$ & 416.67 & 0.19 & $\begin{array}{c}y=125.4 x+118.3 \\
R^{2}=0.96\end{array}$ & 0.11 \\
\hline Silmandi & $\begin{array}{c}y=0.389 x+1.9862 \\
R^{2}=0.93\end{array}$ & 0.40 & 97.59 & $\begin{array}{c}\mathrm{y}=0.0021 \mathrm{x}+0.0085 \\
\mathrm{R}^{2}=0.99\end{array}$ & 500.00 & 0.25 & $\begin{array}{c}y=130.37 x+174.62 \\
R^{2}=0.98\end{array}$ & 0.08 \\
\hline Ghatail & $\begin{array}{c}\mathrm{y}=0.4583 \mathrm{x}+2.0471 \\
\mathrm{R}^{2}=0.96\end{array}$ & 0.46 & 111.46 & $\begin{array}{c}y=0.0012 x+0.0088 \\
R^{2}=0.97\end{array}$ & 833.33 & 0.13 & $\begin{array}{c}y=225.71 x+216.78 \\
R^{2}=0.91\end{array}$ & 0.11 \\
\hline Gopalpur & $\begin{array}{c}\mathrm{y}=0.5199 \mathrm{x}+1.9431 \\
\mathrm{R}^{2}=0.88\end{array}$ & 0.52 & 87.72 & $\begin{array}{c}y=0.0015 x+0.0078 \\
R^{2}=1.0\end{array}$ & 666.67 & 0.19 & $\begin{array}{c}y=233.14 x+169.93 \\
R^{2}=0.95\end{array}$ & 0.19 \\
\hline Ishurdi & $\begin{array}{c}\mathrm{y}=0.4819 \mathrm{x}+1.9098 \\
\mathrm{R}^{2}=1.0\end{array}$ & 0.48 & 81.25 & $\begin{array}{c}y=0.0013 x+0.0158 \\
R^{2}=0.94\end{array}$ & 769.23 & 0.08 & $\begin{array}{c}\mathrm{y}=208.02 \mathrm{x}+151.19 \\
\mathrm{R}^{2}=0.85\end{array}$ & 0.19 \\
\hline Ghior & $\begin{array}{c}y=0.5873 x+1.945 \\
R^{2}=0.96\end{array}$ & 0.59 & 88.10 & $\begin{array}{c}y=0.001 x+0.0102 \\
R^{2}=0.98\end{array}$ & 1000.00 & 0.10 & $\begin{array}{c}y=311.71 x+184.73 \\
R^{2}=0.87\end{array}$ & 0.26 \\
\hline
\end{tabular}

$\mathrm{X}=$ total sorbed $\mathrm{P} ; \mathrm{C}=$ equilibrium $\mathrm{P}$ concentration in solution; $\mathrm{K}_{\mathrm{f}}$ and $\mathrm{N}$ are empirical constants; $\mathrm{b}_{\mathrm{L}}=$ Phosphate sorption maximum; $\mathrm{K}_{\mathrm{L}}=\mathrm{P}$ binding strength; $\mathrm{a}$ and $\mathrm{b}$ are also constants; $\mathrm{EPC}_{0}=$ equilibrium $\mathrm{P}$ concentration in solution.

Table 3. Phosphate desorption from soil by different extractants at different extractant to soil ratios.

\begin{tabular}{|c|c|c|c|c|}
\hline \multirow{2}{*}{ Soil series } & \multirow{2}{*}{$\begin{array}{l}\text { Extractant to } \\
\text { soil ratio }\end{array}$} & \multicolumn{3}{|c|}{ Amount of phosphate desorbed by different extractants $\left(\mathrm{mg} \cdot \mathrm{P} \cdot \mathrm{kg}^{-1}\right.$ soil $)$} \\
\hline & & Sulphate $\left(\mathrm{SO}_{4}^{2-}\right)$ & Bicarbonate $\left(\mathrm{HCO}_{3}^{-}\right)$ & Dist. Water $\left(\mathrm{H}_{2} \mathrm{O}\right)$ \\
\hline \multirow[t]{3}{*}{ Baliadangi } & $30: 1$ & $102.4 \pm 0.8$ & $185.3 \pm 2.5$ & $113.3 \pm 1.1$ \\
\hline & $60: 1$ & $139.3 \pm 2.0$ & $258.1 \pm 0.6$ & $142.3 \pm 0.2$ \\
\hline & 100:1 & $163.2 \pm 1.1$ & $317.3 \pm 2.5$ & $189.6 \pm 0.2$ \\
\hline \multirow[t]{3}{*}{ Gangachara } & $30: 1$ & $85.0 \pm 0.8$ & $143.1 \pm 0.8$ & $98.9 \pm 0.3$ \\
\hline & $60: 1$ & $198.6 \pm 0.2$ & $207.1 \pm 2.8$ & $134.3 \pm 1.1$ \\
\hline & 100:1 & $248.1 \pm 1.2$ & $246.1 \pm 1.7$ & $156.4 \pm 2.2$ \\
\hline \multirow[t]{3}{*}{ Lokdeo } & $30: 1$ & $57.2 \pm 2.8$ & $89.2 \pm 2.4$ & $68.8 \pm 4.2$ \\
\hline & $60: 1$ & $73.4 \pm 1.9$ & $135.7 \pm 2.4$ & $81.7 \pm 3.3$ \\
\hline & 100:1 & $109.2 \pm 3.4$ & $165.8 \pm 4.1$ & $96.8 \pm 3.2$ \\
\hline \multirow[t]{3}{*}{ Silmandi } & $30: 1$ & $73.4 \pm 2.2$ & $132.0 \pm 3.0$ & $78.2 \pm 2.5$ \\
\hline & $60: 1$ & $101.9 \pm 3.3$ & $195.6 \pm 1.9$ & $110.3 \pm 2.9$ \\
\hline & 100:1 & $125.1 \pm 3.1$ & $220.7 \pm 1.6$ & $141.2 \pm 2.1$ \\
\hline \multirow[t]{3}{*}{ Ghatail } & $30: 1$ & $96.9 \pm 1.1$ & $117.4 \pm 2.6$ & $112.3 \pm 1.6$ \\
\hline & $60: 1$ & $126.4 \pm 2.1$ & $172.7 \pm 1.6$ & $138.8 \pm 1.5$ \\
\hline & 100:1 & $154.3 \pm 2.2$ & $220.8 \pm 3.1$ & $164.4 \pm 1.0$ \\
\hline \multirow[t]{3}{*}{ Gopalpur } & $30: 1$ & $127.5 \pm 3.7$ & $139.3 \pm 1.1$ & $120.5 \pm 2.9$ \\
\hline & $60: 1$ & $156.2 \pm 1.6$ & $187.6 \pm 2.3$ & $155.8 \pm 3.0$ \\
\hline & 100:1 & $189.8 \pm 3.4$ & $223.4 \pm 2.1$ & $177.6 \pm 2.9$ \\
\hline \multirow[t]{3}{*}{ Iahurdi } & $30: 1$ & $167.5 \pm 3.8$ & $186.4 \pm 5.3$ & $182.1 \pm 3.4$ \\
\hline & $60: 1$ & $236.2 \pm 3.4$ & $267.7 \pm 2.2$ & $245.8 \pm 0.6$ \\
\hline & 100:1 & $295.4 \pm 2.9$ & $325.1 \pm 3.3$ & $294.9 \pm 3.6$ \\
\hline \multirow[t]{3}{*}{ Ghior } & $30: 1$ & $143.3 \pm 2.1$ & $164.3 \pm 3.1$ & $161.5 \pm 4.0$ \\
\hline & $60: 1$ & $199.9 \pm 2.4$ & $227.4 \pm 3.7$ & $211.0 \pm 1.3$ \\
\hline & 100:1 & $228.5 \pm 3.5$ & $265.5 \pm 3.3$ & $255.2 \pm 1.6$ \\
\hline
\end{tabular}

\pm denotes standard deviation. 
Exchangeable Anions, Water Molecules and Solution to Soil Ratios

Table 4. Analysis of variance (ANOVA) in phosphate desorption due to soil series, extractants and extractant to soil ratios.

\begin{tabular}{lcccc}
\hline Sources of variation (S. V.) & Sum of Squares (S.S) & Degree of freedom (D.F) & Mean sum of square (M.S.S) & Variance ratio (F $\mathrm{F}_{\text {calculated }}$ \\
\hline Soil_Series (S_s) & 123,674 & 7 & 17,667 & $3.508 \mathrm{E} 3^{*}$ \\
Extractant (E) & 146,772 & 2 & 73,386 & $1.457 \mathrm{E} 4^{*}$ \\
Extractant Soil ratio (E_S_r) & 174,554 & 2 & 87,277 & $1.733 \mathrm{E} 4^{*}$ \\
S_s Vs E interaction & 42,784 & 14 & 3056 & $606.778^{*}$ \\
S_s Vs E_S_rinteraction & 3585 & 14 & 256 & $50.856^{*}$ \\
E Vs E_S_rinteraction & 11,998 & 4 & 2999 & $595.557^{*}$ \\
S_s Vs E Vs E_S_rinteraction & 2960 & 28 & 105 & $20.996^{*}$ \\
Error & 725 & 144 & 5 & \\
Total & $5,301,828$ & 216 & &
\end{tabular}

*Significant at $0.1 \%$ level of significance.

Table 5. Correlation between the amount of phosphorus desorbed and different soil parameters, for different extractants at different extractant to soil ratios.

\begin{tabular}{cccccccccc}
\hline \multirow{2}{*}{ Soil Properties } & \multicolumn{3}{c}{ Sulphate $\left(\mathrm{SO}_{4}^{2-}\right)$} & \multicolumn{3}{c}{ Bicarbonate $\left(\mathrm{HCO}_{3}^{-}\right)$} & \multicolumn{2}{c}{ Dist. Water $\left(\mathrm{H}_{2} \mathrm{O}\right)$} \\
\cline { 2 - 9 } & $30: 1$ ratio & $60: 1$ ratio & $100: 1$ ratio & $30: 1$ ratio & $60: 1$ ratio & $100: 1$ ratio & $30: 1$ ratio & $60: 1$ ratio & $100: 1$ ratio \\
\hline \% Clay & $0.74^{*}$ & $0.76^{*}$ & $0.71^{*}$ & 0.48 & 0.46 & 0.44 & $0.81^{* *}$ & $0.81^{* *}$ & $0.79^{* *}$ \\
Iron Oxide & $0.70^{*}$ & $0.72^{*}$ & $0.69^{*}$ & 0.30 & 0.34 & 0.34 & $0.78^{*}$ & $0.76^{*}$ & $0.73^{*}$ \\
pH & $0.78^{*}$ & $0.74^{*}$ & $0.71^{*}$ & 0.24 & 0.17 & 0.18 & $0.75^{*}$ & $0.71^{*}$ & $0.66^{*}$ \\
\hline
\end{tabular}

${ }^{* *}$ Correlation is significant at 0.01 level; ${ }^{*}$ Correlation is significant at 0.05 level.

iron oxide content of the soils.

\subsection{Relationship between Phosphate Sorption Parameters and Desorption}

The amounts of phosphate desorbed by $0.005 \mathrm{M} \mathrm{SO}_{4}^{2-}$, $0.01 \mathrm{M} \mathrm{HCO}_{3}^{-}$and distilled water were significantly correlated $(\mathrm{r}>0.64, \mathrm{P}<0.05)$ with phosphorus sorption maximum $\left(b_{L}\right)$ values determined from Langmuir equation. Such a relationship is supported by other scientists [36], who found a high significant correlation between the fractions of added phosphate recovered by $\mathrm{NaHCO}_{3}$ with the sorption maximum. Phosphate desorption by $0.005 \mathrm{M} \mathrm{SO}_{4}^{2-}$ and distilled water was positively correlated with Freundlich constant, N $(r>0.67, \mathrm{P}<0.05)$ and $\mathrm{EPC}_{0}(\mathrm{r}>0.72, \mathrm{P}<0.05)$ but this was not the case when the displacing ion was $0.01 \mathrm{M} \mathrm{HCO}_{3}^{-}$. On the other hand, $\mathrm{P}$ desorption by all the three extractants was negatively correlated $(\mathrm{r}>-0.77, \mathrm{P}<0.05)$ with phosphate binding strength $\left(\mathrm{K}_{\mathrm{L}}\right)$, estimated from Langmuir equation (Table 6).

\section{Discussion}

Among the three sorption equations, the Langmuir equation showed better fit to the sorption data. As equilibrium phosphorus concentration $\left(\mathrm{EPC}_{0}\right)$ value estimates the intensity of $\mathrm{P}$ in the soil, higher $\mathrm{EPC}_{0}$ values suggested much greater $\mathrm{P}$ intensity in calcareous soils than non- calcareous soils. Again, rainfall or subsurface drainage with little $\mathrm{P}$ in water will subsequently desorb more $\mathrm{P}$ from soil particles or sediments that have higher $\mathrm{EPC}_{0}$ values. Conversely, solid phases with small $\mathrm{EPC}_{0}$ values will act as sinks for $\mathrm{P}$ by reducing $\mathrm{P}$ concentration of stream flow or runoff and thus will decrease the potential for downstream eutrophication [37]. Among the studied soils, the non-calcareous soils had small $\mathrm{EPC}_{0}$ values and would act as sinks and the calcareous soils, with large $\mathrm{EPC}_{0}$ values would act as a source of $\mathrm{P}$ when they will be amended with an equal amount of $\mathrm{P}$ fertilizer.

Phosphate desorption increased with the increasing solution to soil ratios. The results imply that more phosphate ions tend to be desorbed from the soil colloids to maintain equilibrium between the sorbed $\mathrm{P}$ and the solution $\mathrm{P}$ at higher solution to soil ratio. Phosphate desorption by different extractants followed the order of $\mathrm{SO}_{4}^{2-}$ $=\mathrm{H}_{2} \mathrm{O}>\mathrm{HCO}_{3}^{-}$. Significant desorption of phosphate by different extractants suggests that bicarbonate and sulphate ions increased the negative charge of the soil in the presence of phosphate [6,7]. Freshly added phosphate ions were bonded through single coordinate linkage [5, 8]. These ions are considered as labile forms of $\mathrm{P}$, which were easily desorbed in the soil solution by $\mathrm{SO}_{4}^{2-}$, $\mathrm{HCO}_{3}^{-}$and distilled water. Significant relationships among different soil sorption parameters and phosphate desorption indicate the importance of these parameters in phosphate desorption study. 
Table 6. Correlation between the amount of phosphorus desorbed and different soil sorption parameters, for different extractants at different extractant to soil ratios.

\begin{tabular}{cccccccccc}
\hline \multirow{2}{*}{ Sorption parameters } & \multicolumn{3}{c}{ Sulphate $\left(\mathrm{SO}_{4}^{2-}\right)$} & \multicolumn{3}{c}{ Bicarbonate $\left(\mathrm{HCO}_{3}^{-}\right)$} & \multicolumn{3}{c}{ Dist. Water $\left(\mathrm{H}_{2} \mathrm{O}\right)$} \\
\cline { 2 - 10 } & $30: 1$ ratio & $60: 1$ ratio & $100: 1$ ratio & $30: 1$ ratio & $60: 1$ ratio & $100: 1$ ratio & $30: 1$ ratio & $60: 1$ ratio & $100: 1$ ratio \\
\hline $\mathrm{N}$ & $0.77^{*}$ & $0.74^{*}$ & $0.67^{*}$ & 0.39 & 0.30 & 0.29 & $0.74^{*}$ & $0.70^{*}$ & $0.68^{*}$ \\
$\mathrm{~b}_{\mathrm{L}}$ & $0.64^{*}$ & $0.64^{*}$ & $0.66^{*}$ & $0.70^{*}$ & $0.66^{*}$ & $0.69^{*}$ & $0.70^{*}$ & $0.66^{*}$ & $0.70^{*}$ \\
$\mathrm{~K}_{\mathrm{L}}$ & $-0.67^{*}$ & $-0.69^{*}$ & $-0.68^{*}$ & $-0.69^{*}$ & $-0.69^{*}$ & $-0.77^{*}$ & $-0.77^{*}$ & $-0.71^{*}$ & $-0.74^{*}$ \\
$\mathrm{EPC}_{0}$ & $0.78^{*}$ & $0.76^{*}$ & $0.73^{*}$ & 0.32 & 0.25 & 0.24 & $0.75^{*}$ & $0.72^{*}$ & $0.72^{*}$ \\
\hline
\end{tabular}

$\mathrm{N}=$ empirical constant of Freundlich equation, $\mathrm{b}_{\mathrm{L}}=$ Phosphate sorption maximum; $\mathrm{K}_{\mathrm{L}}=\mathrm{P}$ binding strength; $\mathrm{EPC}_{0}=$ equilibrium $\mathrm{P}$ concentration in solution ${ }^{*}$ Correlation is significant at 0.05 level.

\section{Conclusion}

Sulphate, bicarbonate and distilled water desorbed the maximum amounts of phosphate from the soil colloids at the largest extractant to soil ratio. Although phosphate ions are principally adsorbed as inner-sphere complex species, freshly added ions were readily desorbed by other ions like sulphate, bicarbonate and water molecules. These results imply that the freshly sorbed P ions in soil are highly mobile. When provided with the same concentration of $\mathrm{P}$ in solution, calcareous soil will release more phosphate than non-calcareous soils. As a result, more phosphorus would become available from labile pool of calcareous soils than that of non-calcareous soils.

\section{REFERENCES}

[1] M. C. Paulter and J. T. Sims, "Relationships between Soil Test Phosphorus, Soluble Phosphorus and Phosphorus Saturation in Delaware Soils," Soil Science Society of America Journal, Vol. 64, No. 2, 2000, pp. 765-773. doi:10.2136/sssaj2000.642765x

[2] M. Jalali and E. N. Peikam, "Phosphorus Sorption-Desorption Behavior of River Bed Sediments in the Abshineh River, Hamedan, Iran, Related to Their Composition," Environmental Monitoring and Assessment, 2012. doi:10.1007/s10661-012-2573-5

[3] B. W. Bache and E. G. Williams, "A Phosphate Sorption Index for Soils," Journal of Soil Science, Vol. 22, No. 3, 1971, pp. 289-301. doi:10.1111/j.1365-2389.1971.tb01617.x

[4] M. I. Temkin and V. Pyzhev, "Kinetic of Ammonia Synthesis on Promoted Iron Catalysts," Acta Physiochim, Vol. 12, 1940, pp. 327-356.

[5] G. Sposito, "The Chimistry of Soils," Oxford University Press, New York, 1989, pp. 148-165.

[6] F. J. Hingston, A. M. Posner and J. P. Quirk, "Anion Adsorption by Goethite and Gibbsite. I. Role of the Proton in Determining Adsorption Envelopes," Journal of Soil Science, Vol. 23, No. 2, 1972, pp. 177-192. doi:10.1111/j.1365-2389.1972.tb01652.x

[7] F. J. Hingston, A. M. Posner and J. P. Quirk, "Anion Adsorption by Goethite and Gibbsite. II. Desorption of
Anions from Hydrous Oxide Surfaces," Journal of Soil Science, Vol. 25, No. 1, 1974, pp. 16-26. doi:10.1111/j.1365-2389.1974.tb01098.x

[8] H. L. Bohn, B. L. McNealand and G. A. O'Connor, "Soil Chemistry," 3rd Edition, John Wiley and Sons Inc., New York, 2011.

[9] N. J. Barrow, "The Description of Desorption of Phosphate from Soil," Journal of Soil Science, Vol. 30, No. 2, 1979, pp. 259-270. doi:10.1111/j.1365-2389.1979.tb00983.x

[10] P. A. Vadas and J. T. Sims, "Predicting Phosphorus Desorption from Mid-Atlantic Coastal Plain Soil," Soil Science Society of America Journal, Vol. 66, No. 2, 2002, pp. 623-631. doi:10.2136/sssaj2002.0623

[11] M. C. Horta and J. Torrent, "The Olsen P Method as an Agronomic and Environmental Test for Predicting Phosphate Release from Acid Soils," Nutrient Cycling in Agroecosystems, Vol. 77, No. 3, 2007, pp. 283-292. doi:10.1007/s10705-006-9066-2

[12] R. E. White, "Studies on the Phosphate Potentials of Soils. IV. The Mechanism of the Soil/Solution Ratio Effect," Australian Journal of Soil Research, Vol. 4, No. 1, 1966, pp. 77-85. doi:10.1071/SR9660077

[13] G. D. Hope and J. K. Syers, "Effects of Solution to Soil Ratio on Phosphate Sorption by Soils," Journal of Soil Science, Vol. 27, No. 3, 1976, pp. 301-306. doi:10.1111/j.1365-2389.1976.tb02000.x

[14] M. L. Leclerc, M. C. Nolin, D. Cluis and R. R. Simard, "Grouping Soils of the Montreal Lowlands (Quebec) According to Fertility and P Sorption and Desorption Characteristics," Canadian Journal of Soil Science, Vol. 81, No. 1, 2001, pp. 71-83. doi:10.4141/S00-021

[15] K. Daly, D. Jeffrey and H. Tunney, "The Effect of Soil Type on Phosphorus Sorption Capacity and Desorption Dynamics in Irish Grassland Soils," Soil Use Management, Vol. 17, No. 1, 2001, pp. 12-20. doi:10.1111/j.1475-2743.2001.tb00003.x

[16] G. S. Toor, G. S. Bahl and A. C. Vig, "Pattern of P Availability in Different Soils as Assessed by the Adsorption Equations," Journal of Indian Society of Soil Science, Vol. 45, No. 4, 1997, pp. 719-723.

[17] N. J. Barrow, "Modeling the Effects of pH on Phosphate Sorption by Soils," Journal of Soil Science, Vol. 35, No. 2, 1984, pp. 283-297. 


\section{doi:10.1111/j.1365-2389.1984.tb00283.x}

[18] I. Bertrand, R. E. Holloway, R. D. Armstrong and M. J. MCLaughlin, "Chemical Characteristics of Phosphorus in Alkaline Soils from Southern Australia," Australian Journal of Soil Research, Vol. 41, No. 1, 2003, pp. 61-76. doi:10.1071/SR02021

[19] I. C. R. Holford and G. E. G. Mattingly, "The High- and Low-energy Phosphate Adsorbing Surfaces in Calcareous Soils," Journal of Soil Science, Vol. 26, No. 4, 1974, pp. 407-417. doi:10.1111/j.1365-2389.1975.tb01964.x

[20] IUSS Working Group WRB, "World Reference Base for Soil Resources 2006," World Soil Resources Reports No. 103, FAO, Rome, 2006.

[21] G. J. Bouyoucos, "The Hydrometer as a New Method for the Mechanical Analysis of Soils," Soil Science, Vol. 23, No. 4, 1927, pp. 343-353. doi:10.1097/00010694-192705000-00002

[22] A. Walkley and I. A. Black, "An Examination of the Degtjareff Method for Determining Soil Organic Matter and a Proposed Modification of the Chromic Acid Titration Method," Soil Science, Vol. 37, 1934, pp. 29-38.

[23] M. L. Jackson, "Soil Chemical Analysis," Prentice-Hall, Inc., Upper Saddle River, 1973, pp. 38-56.

[24] S. R. Olsen, C. V. Coles, F. S. Watanabe and L. A. Dean, "Estimation of Available Phosphorus in Soils by Extraction with Sodium Bicarbonate," USDA Circ. 939, USDA, Washington DC, 1954.

[25] J. Murphy and J. P. Riley, “A Modified Single Solution Method for the Determination of Phosphate in Natural Waters," Analytica Chemica Acta, Vol. 27, 1962, pp. 3136. doi:10.1016/S0003-2670(00)88444-5

[26] L. E. Allison and C. D. Moodie, "Carbonate," In: C. A. Black, Ed., Methods of Soil Analysis. Part 2: Chemical and Microbiological Properties, Agronomy, Madison, Wisconsin, 1965, pp. 1379-1398.

[27] G. S. Holmgren, "A Rapid Citrate-Dithionate Extractable Iron Procedure," Soil Science Society of America Proceedings, Vol. 31, 1967, pp. 210-221.

[28] J. A. Mckeague and J. H. Day, "Dithionate and Oxalate Extractable $\mathrm{Fe}$ and $\mathrm{Al}$ as Aids in Differentiating Various
Classes of Soils," Canadian Journal of Soil Science, Vol. 46, 1966, pp. 13-22. doi:10.4141/cjss66-003

[29] C. L. Bascomb, "Distribution of Pyrophosphate-Extractable Iron and Organic Carbon in Soils of Various Groups," Journal of Soil Science, Vol. 19, No. 1, 1968, pp. 251-258. doi:10.1111/j.1365-2389.1968.tb01538.x

[30] R. V. Olson and R. Ellis, "Iron," In: C. A. Black, Ed., Methods of Soil Analysis, Part 2, Agronomy, Monograph 9, ASA and SSSA, Madison, 1982, pp. 301-312.

[31] A. N. Sharpley, L. R. Ahuja, M. Yamamoto and R. G. Menzel, "The Kinetics of Phosphorus Desorption from Soil," Soil Science Society of America Journal, Vol. 45, No. 3, 1981, pp. 493-496. doi:10.2136/sssaj 1981.03615995004500030010x

[32] I. Langmuir, "The Adsorption of Gases on Plane Surfaces of Glass, Mica and Platinum," Journal of American Chemical Society, Vol. 40, No. 9, 1918, pp. 1361-1402. doi:10.1021/ja02242a004

[33] H. Freundlich, "Colloid and Capillary Chemistry," Methuen, London, 1926, pp. 114-122.

[34] M. Z. Afsar, S. Hoque and K. T. Osman, "A Comparison of the Langmuir, Freundlich and Temkin Equations to Describe Phosphate Sorption Characteristics of Some Representative Soils of Bangladesh," International Journal of Soil Science, Vol. 7, No. 3, 2012, pp. 91-99.

[35] M. Emadi, M. M. Baghernejad, M. Emadi, H. Fathi and M. Saffari, "Phosphorus Forms and Behaviors in Selected Heavily Fertilized Soils," Archieves of Agronomy and Soil Science, Vol. 55, No. 6, 2009, pp. 579-595. doi:10.1080/03650340902889796

[36] S. E. Kuo, J. Jellum and W. L. Pan, "Influence of Phosphate Sorption Parameters of Soils on the Desorption of Phosphate by Various Extractants," Soil Science Society of America Journal, Vol. 52, No. 4, 1988, pp. 974-979. doi:10.2136/sssaj1988.03615995005200040014x

[37] K. Zhou and Y. Li, "Phosphorus-Sorption Characteristics of Soils and Limestone from the Southern Everglades and Adjacent Farmlands," Soil Science Society of America Journal, Vol. 65, No. 5, 2011, pp. 1404-1412. doi:10.2136/sssaj2001.6551404x 